\title{
THE BOOK OF JOB AND THE FEAR OF GOD
}

\author{
Lindsay Wilson
}

\section{Summary}

This article studies the function of the 'fear of God' idea in the book of $J o b$. It is argued that, despite the difference in terminology, the 'fear of God' is equivalent to the 'fear of the LORD' concept of Proverbs. The location of the motif in the final form of the book of Job suggests that the 'fear of God' is not being proposed as the answer to Job's dilemma. Rather, Job is one who maintains his 'fear of God' throughout the book, yet is left with his questions and suffering. The 'fear of God' is seen as the solution by Job's friends, the wisdom interlude of chapter 28, and by Elihu, yet all this is overridden by the Yahweh speeches and epilogue, where the 'fear of God' is not mentioned. While the 'fear of God' is central to the wisdom stream, the book of Job establishes that it is not the answer to every problem in life.

\section{Introduction: The 'Fear of the LORD' in Wisdom Literature}

Since the 'fear of the LORD' is a concept of utmost importance in the OT, it is surprising that no major monograph has been written in English on the subject, and those that have appeared in French and German are now over 25 years old. ${ }^{1}$ It is appropriate, then, to re-examine how this pivotal idea is understood in the wisdom tradition.

1S. Plath, Furcht Gottes. Der Begriff יר im Alten Testament (Stuttgart: Calwer Verlag, 1963); J. Becker, Gottesfurcht im Alten Testament (Analecta Biblica 25; Rome: Pontifical Biblical Institute, 1965); L. Derousseaux, La crainte de Dieu dans l'Ancien Testament (Paris: Cerf, 1970). See also the more recent articles by M.L. Barré, "Fear of God" and the World View of Wisdom', BTB 11 (1981) 41-43; H. Blocher, 'The Fear of the Lord as the "Principle" of Wisdom", TynB 28 (1977) 3-28; J. Marböck, 'Im Horizont der Gottesfurcht: Stellungnahme zu Welt und Leben in der alttestamentlichen Weisheit', BN 26 (1985) 47-70. 
The 'fear of the LORD' is prominent in both wisdom and non-wisdom texts. In the covenant strand of the OT, the 'fear of the LORD' (or Yahweh) is most evident in Deuteronomy (e.g., 4:10; 5:29; 6:2, 13, 24; 10:12, 20), but it is also common in the historical books (e.g., 1 Sa. 12:14, 24; $1 \mathrm{Ki} .8: 40$, $43 ; 2$ Ch. 19:7, 9) and the prophets (e.g., Is. 11:2-3; Je. 5:22-24; Mal. 3:5). Yet, this fear of Yahweh is also woven into the fabric of the wisdom books, in which Israel's salvation history is strangely absent. It is both frequent and structurally important in the book of Proverbs (e.g., 1:7; 9:10; 31:30); it is prominent in the final form of Ecclesiastes (especially 12:13); and it is woven through the book of Job. The expression is even found in two 'wisdom psalms' (Pss. 34:11; 111:10). The only mainstream wisdom book in which the 'fear of the LORD' idea does not appear is the Song of Songs.

Some have even regarded it as the central notion of the wisdom literature. Kaiser asserts that:

the fear of the Lord was the dominating concept and organizing theological principle in wisdom literature. It was the response of faith to the divine word of promise and blessing just as it had functioned in the days of Abraham and Moses. $^{2}$

Kidner, while not going as far, writes about the fear of the LORD as follows:

In one form or another this truth meets us in all the wisdom books, and it is this that keeps the shrewdness of Proverbs from slipping into mere self-interest, the perplexity of Job from mutiny, and the disillusion of Ecclesiastes from final despair. $^{3}$

The difficulty of linking the wisdom literature with the rest of the OT makes the concept of the 'fear of the LORD' an especially inviting one. Since it is a term that is prominent both in wisdom texts, and in the covenant strand, it may well be a

${ }^{2}$ W.C. Kaiser, Toward an Old Testament Theology (Grand Rapids: Zondervan, 1978) 170.

${ }^{3}$ D. Kidner, Wisdom to Live By (Leicester: IVP, 1985) 17. 
useful concept for the integration of the two. To date, most of the scholarly attention on the 'fear of the LORD' has focused on the book of Proverbs, and the way in which the 'fear of God' idea functions in the book of Job has not yet been thoroughly explored. This article aims to do some preliminary work in this area.

This article assumes that the immediate literary setting of the book of Job (i.e., the OT wisdom corpus) is a very fruitful context for interpretation. For this reason, there is a need to outline how the 'fear of the LORD' concept is developed in the other wisdom books before turning to the book of Job itself.

\section{The 'Fear of the LORD' in the Book of Proverbs}

The phrase 'the fear of the LORD' occurs frequently in Proverbs, being found in Proverbs 1:7 (it is the beginning, or first principle of knowledge); 1:29 (it needs to be chosen); 2:4-5 (it is a way of living that can be mastered, but it must to be searched for); 8:13 (the fear of the LORD is to hate evil and evil ways); 9:10 (it is the beginning of wisdom); 10:27 (it leads to a longer life); 14:26-27 (the fear of the LORD gives security, and is a fountain of life); 15:16 (it is more valuable than great treasure); 15:33 (it is the instruction of wisdom); 16:6 (it is better than gold); 19:23 (it leads to life, and gives satisfaction); 22:4 (its reward is riches, honour and life); 23:17 (it is a constant state for one who trusts in the LORD); $31: 30$ (the perfect woman of $31: 10-31$ is one who fears the LORD). The verbal form ('fear the LORD') is found in 3:7 and 24:21.

However, it is not only the number of occurrences that is noteworthy. The motif of the 'fear of the LORD' also has an important structural location in the book of Proverbs. The final form of the book invites the reader to pass through chapters 19 first, so that the teaching of this section shapes the way that the rest of the book is to be read. The sentence literature of chapters 10-29 is not designed to be read in isolation from the book as a whole. Chapters 1-9 focus on the formation of a godly character that comes from embracing wisdom, which is then presupposed in the individual proverbial sayings. 
Therefore, it is significant that the fear of the LORD sayings are prominent towards the beginning and end of chapters 1-9. Proverbs 1:7 is the climax to the prologue (Pr. 1:2-7), and the foundational, perhaps even programmatic 'fear of the LORD' saying. ${ }^{4}$ A similar saying is also found in 9:10 by way of inclusio. Furthermore, it is again found in a prominent structural position in the coda that ends the book in 31:10-31 (especially v. 30). This may be even more significant since this 'perfect woman' is perhaps a personification of wisdom-a picture of Lady Wisdom herself. The positioning of the motif in the book testifies to the centrality of the idea in the book as a whole.

The prominence of the concept in Proverbs is all the more remarkable in that there is nothing comparable to the motto 'the fear of the LORD is the beginning of Wisdom' in other ANE wisdom literature. ${ }^{5}$ Although Proverbs has had a close connection with Egyptian wisdom literature (e.g., the wisdom of Amenemope and Pr. 22-24), the emphasis on the 'fear of the LORD' as a central concept, seems distinctive to the Israelite proverbial literature. Much more could be said about the 'fear of the LORD' in Proverbs, but that is not the focus of this article.

\section{The 'Fear of God' in the Book of Ecclesiastes}

Qoheleth does not use either the 'fear of the LORD' or the 'fear of God' but instead employs the verbal form ('fear God'). The number of passages in which Qoheleth speaks of the 'fear of God' is small: 3:14; 5:7 [6]; 7:18; 8:12-13 and 12:13.6 In 3:11-

\footnotetext{
רִאשִית means 'beginning' or 'first principle', see Blocher, 'The Fear of the Lord', 3-28.

5ee Derousseaux, La crainte de Dieu, 21-66 for a detailed study of the 'fear of God' concept in Egyptian, Akkadian, Aramaic and Ugaritic texts. He notes that the fear of the king is much stronger than the 'fear of God'.

${ }^{6}$ Apart from the books mentioned in footnote 1 , the question of the 'fear of God' in Ecclesiastes is explored in E. Pfeiffer, 'Die Gottesfurcht im Buche Kohelet', in Gottes Wort und Gottes Land (Fs. H.-W.
} 
14 , God's action as creator should elicit a response of 'fear before him', the content of which is not filled in. At 5:7 [6] there is an abrupt command to fear God (in the setting of worship). In the context of 5:1-7 [4:17-5:6], it seems that the fear of God is equated with avoiding the foolish behaviour outlined in 5:1-6 [4:17-5:5]. In 7:18 those who fear God are regarded favourably by Qoheleth, and this seems to refer to those who avoid the self-destructive conduct of 7:16-17.7

The more significant occurrences are those of chapters 8 and 12. In 8:12-13 those who fear God are contrasted with 'sinners' or 'the wicked', a usage which is closest to that of Proverbs. Those who fear God will prosper and their days will be prolonged. Clearly, this is the same idea as the 'fear of the LORD' in Proverbs, despite the use of אלדהים for 'God'.

The most vital reference in Ecclesiastes is 12:13, where fearing God (אלהים) is linked with obeying God's commands. Though many suggest that the epilogue (Ec. 12:9-14) is not from Qoheleth's hand, it is part of the final form of the book. As such, it serves both to commend the previous questioning of the rest of the book (vv. 9-10), as well as lay down a foundational principle of interpretation and for daily living (v. 13). ${ }^{8}$ While the epilogue thus serves to tie Ecclesiastes to the book of Proverbs through the 'fear of God', ${ }^{9}$ the endorsement of the other words of Qoheleth, makes it clear that the questioning of the meaning of life, and God's purposes, is still consistent with fearing God. Ecclesiastes is full of such questioning, yet the epilogue endorses the words of Qoheleth.

Hertzberg; ed H.G. Reventlow; Göttingen: Vandenhoeck \& Ruprecht, 1965) 133-158.

7For a discussion of the concept of the 'fear of God' in these passages, see H.F. Fuhs, $\times$, TDOT Vol. 6, 312-313.

${ }^{8}$ Thus, G.H. Wilson, "The Words of the Wise": The Intent and Significance of Qoheleth 12:9-14', JBL 103 (1984) 178.

${ }^{9} \mathrm{As}$ is strongly argued by Wilson, 'The Words of the Wise', 179-183. In particular, the epilogue to Ecclesiastes and the prologue to Proverbs show strong correspondences of theme, structure and function. 


\section{The 'Fear of the LORD' and the 'Fear of God'}

The question of whether the fear of God is the same as the 'fear of the LORD' has so far only been dealt with in passing. This will be important for the book of Job which, like Ecclesiastes, does not use the phrase the 'fear of the LORD'. It seems fairly clear from Ecclesiastes 8:12-13 that a writer can refer to the classical 'fear of the LORD' motif, yet do so by speaking of 'fearing God'.

It is further likely that the reference to 'fearing God' in the epilogue of Ecclesiastes is an allusion to the foundational wisdom principle of Proverbs. ${ }^{10}$ Terminology, in particular the use or non-use of 'Yahweh', does not appear to be decisive. This is not surprising since the wisdom writers were Israelites for whom Yahweh alone was God. As Goldsworthy comments, 'These were Israelites and, although salvation history is not a theme of their writing, they were not unbelieving philosophers professing a humanistic alternative to the covenant faith. ${ }^{\prime 11}$

Of course, 'fear of God' does not necessarily denote exactly the same as 'fear of the LORD'. At times it seems to refer to little more than a basic morality, a sense of right and wrong. Thus, Abraham in Gerar is fearful and lies because he distrusted the moral atmosphere of Abimelech's court- 'there is no fear of God in this place' (Gn. 20:11). Similarly, the midwives 'feared God' in Exodus 1:17, 21 (that is, they had a basic respect for life), while in Deuteronomy 25:17, the Amalekites are said to have no 'fear of God'. Whybray therefore defines the 'fear of God' as 'a standard of moral conduct known and accepted by men in general', a concept included in, but much more restricted than, the 'fear of Yahweh'.12

${ }^{10}$ H.A. Brongers, 'La Crainte du Seigneur' (Jir'at Jhwh, Jir'at 'Elohim)' Oudtestamentische Studiën 5 (1948) 163, argues that the two terms ('fear of Yahweh' and 'fear of God') mean the same thing, and no difference can be demonstrated between the two. He cites as an example Lv. 25:17 (see also Lv. 19:14, 32). It is probably more correct to say that the two terms can sometimes mean the same thing, but that they do not always do so.

${ }^{11}$ G.L. Goldsworthy, Gospel and Wisdom (Exeter: Paternoster, 1987) 70.

${ }^{12}$ R.N. Whybray, Wisdom in Proverbs (SBT 45; London: SCM, 1965) 96. 
However, whether 'fear of God' has this narrower sense, or whether it is co-extensive with the 'fear of the LORD' is not something that can be decided a priori, but rather must be determined from the context in each case.

\section{The 'Fear of God' in the Book of Job}

\section{Previous Scholarship on the 'Fear of God' in Job}

The monographs on the 'fear of the LORD' mentioned in footnote 1, all predate the methodological revolution in OT and Joban studies, which focuses much more on the final form of the text, rather than its pre-history. Their limitations in relation to the book of Job are readily seen. For example, Becker's study is largely a linguistic one, in which he analyses the terminology of the 'fear of God' in the book of Job under the headings of 'the adjective and verb with Elohim'; 'the noun with Shaddai and Adonai'; and 'the absolute use in Eliphaz's speeches'. ${ }^{13} \mathrm{He}$ does not demonstrate how the individual verses that are studied fit into the message of the book as a whole.

Derousseaux criticises the earlier monographs of both Plath and Becker, arguing that they do not seek to understand the book of Job against the background of Israelite wisdom thinking on the 'fear of the LORD'. ${ }^{14}$ This criticism is wellfounded, and the attention to the setting in the wisdom corpus is a helpful aspect of Derousseaux's work. (We will discuss below his view that Job questions the wisdom acceptance of the 'fear of the LORD'.)

Where Derousseaux's treatment of Job is less satisfactory is that he fails to give proper attention to the final form of the book, and how the different parts of Job need to be understood in the context of the whole. One example of this is his omission of two key occurrences-Job 28:28 and 37:24-on the basis that the Elihu speeches, and the last verse of the

13Becker, Gottesfurcht, 242-249, 261.

${ }^{14}$ Derousseaux, La crainte de Dieu, 328. 
wisdom poem, were not the authentic words of the author. ${ }^{15}$ This approach is probably representative of much OT scholarship dating from the 1960's (the thesis underlying the book was submitted in 1968); but scholarship has since moved on. The deletion of these two important references will inevitably lead to skewed findings about how the idea of 'fear of God' is used in the book. Furthermore, although many commentaries have appeared in recent years, they have not yet seriously addressed this crucial idea.

There is, then, no substantial study of the 'fear of God' in the book of Job, that takes note of both the Israelite wisdom background, and the shape of the book as a whole. The time is ripe for a re-assessment of the 'fear of God' concept in the light of its function in the final form of the text of Job.

Such a re-assessment is vital in understanding this very important OT book. Since the book of Job deals with the nature of authentic faith, it will indicate what kinds of address to God are portrayed as permissible. Has Job strayed from the 'fear of God' in his bold words and actions-in which case he is held up before the reader as a warning? Or does he hold on to the 'fear of God', which means that Job's words are permissible? Does Job need to return to the 'fear of the LORD', or does the idea of the 'fear of the LORD' need to be broadened or qualified in order to include or legitimate Job's responses? Such are the questions raised by the book.

\section{The Terminology of the Book}

The expression ירוּ : ('the fear of Yahweh/the LORD') itself appears nowhere in the book of Job. There are several occurrences of 'fearing God' in Job $(1: 1,8,9 ; 2: 3 ; 4: 6 ; 6: 14 ; 15: 4$; $22: 4 ; 28: 28 ; 37: 24)$, though the title for God does vary. The word for God is אֶלה ('Elohim') in 1:1, 8, 9; 2:3; it is ('Shaddai') in 6:14 and 37:24 (implied from verse 23); in 4:6, 15:4, 22:4 the root יר ('to fear') is used without an expressed object to refer

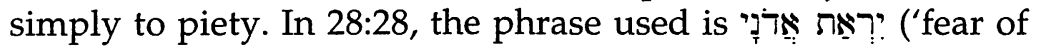
Adonai'). In other places, 'fearing' is used, but not with reference to 'fearing God' $(5: 21,22 ; 6: 21 ; 9: 34,35 ; 11: 15 ; 39: 22)$.

${ }^{15}$ Derousseaux, La crainte de Dieu, 329, 336. 
Sometimes different roots are used $(3: 25 ; 4: 14 ; 21: 9 ; 22: 10 ; 25: 2$; $31: 34 ; 39: 16,22 ; 41: 33$ [25]) which are sometimes translated 'fear' in English, but speak rather of 'terror' (usually the root פחד) and are unrelated to the wisdom notion of the 'fear of the LORD'.

The above study of the book of Ecclesiastes has indicated that the explicit use of the name Yahweh is not essential for establishing the presence of the 'fear of the LORD' motif. What needs to be explored is whether the various expressions which are found in Job are semantically equivalent to the 'fear of Yahweh' as seen in the book of Proverbs. This must be decided contextually in each case before the significance and role of the motif can be fully discerned.

\section{The Prologue}

At the outset, the narrator establishes Job as one who 'feared God' (1:1). Such a reference in the prologue could on its own refer to a common morality, since the setting is in $\mathrm{Uz}(1: 1)$ and not in Israel. This is unlikely, however, for several reasons. Firstly, the book was written for Israel, and Yahweh's endorsement of him in 42:7, 8 implies that he is to some extent a model for Israelites. Secondly, there are good reasons to use 'Yahweh' sparingly in the book of Job. Not only is the story deliberately set outside Israel, it also seeks, as wisdom books characteristically do, to deal with universal problems and not simply those of Israel's national history. In such a context Yahweh is used only in the prologue, Yahweh speeches and epilogue (with one exception-12:9). Thirdly, it is clear that in the context of Job 1 the God who is feared is Yahweh, for there is no other God in the prologue. The narrator's description of Job as one who 'fears God' (1:1) is repeated by Yahweh himself in 1:8 and 2:3. In 1:8, Yahweh himself describes Job as 'my servant Job', who 'fears God'. Fourthly, there appears to be inclusio between Job fearing God in 1:1 and the programmatic statement of $28: 28$. This latter statement is even more clearly referring to the mainstream wisdom idea (see below) and this confirms that 1:1 has the same idea in mind. Finally, the coupling of 'fears God' and 'turns away from evil' (1:1) surely echoes the pairing of the book of Proverbs, which pairs the 
'fear of the LORD' and 'turning away from evil' (Pr. 3:7; 16:6; also 14:16). Derousseaux's objections that these verses are late are not convincing, since the dating of both Proverbs and Job is far from determined. ${ }^{16}$

The prologue's repeated insistence that Job 'fears God', serves to shape the reader's understanding. The 'fear of God' is not something that Job learns in the process of the debate, for he already has this 'fear' in the prologue. It is made very clear that the disasters that befall Job in chapters 1 and 2 occur in spite of the fact that Job has 'feared God'.

Thus, the case of Job puts in doubt the maxim that those who fear God will prosper. On a quick reading of Proverbs, Job may well appear to have become one who did not 'fear the LORD'. He does not seem to have found a refuge for his children (Pr. 14:26), 'a fountain of life' (Pr. 14:27), absence of trouble (Pr. 15:16), a satisfied life (Pr. 19:23) nor 'riches, and honour and life' (Pr. 22:4). If these characterise those who have the 'fear of the LORD', what does this mean for Job?

\section{The Dialogue}

Of the three friends, Eliphaz is the only one to use the word 'fear (of God)' to Job. He employs the word three times (4:6; $15: 4 ; 22: 4)$, once in each cycle. In each case the object is implied and 'fear' is perhaps best translated 'piety'. In 4:6, Eliphaz urges Job to trust in his 'fear/piety'; in 15:4 he accuses him of undermining 'piety'; in 22:4 he appears to use it ironically to ridicule Job. Despite the fact that Eliphaz is not an Israelite (indeed this could be the reason why 'Yahweh' is not explicitly mentioned), he appears to have in mind the traditional wisdom concept of the 'fear of the LORD'. ${ }^{17}$ Eliphaz is espousing a

16Derousseaux, La crainte de Dieu, 330-332, concedes that the terms 'fearing God' and 'turning away from evil' are reflected in Proverbs, and that 'fear of Yahweh' and 'turning away from evil' are in parallel. However, he resists the obvious conclusion when, at 331, he writes 'Mais ces parallèles ne suffisent pas à faire de ces passages de Job des textes proches de Proverbes, car $\operatorname{Pr} 3,7$ et 16, 6 sont tardifs.'

17Fuhs, TDOT 6, 312, describes the absolute use of ירָ: by Eliphaz as representing a shorthand form for the 'fear of the LORD'. Derousseaux, La crainte de Dieu, 333, concedes, for example, in 22:4, that Eliphaz is 
typical wisdom stance, linking piety with prosperity, based on the doctrine of retribution.

Job's sole use of it during the dialogues is in 6:14, where he alleges that Eliphaz's treatment of Job was not 'fearing the Almighty' (שֵָׁ). In the cut and thrust of debate, Job is surely referring to the mainstream wisdom concept (referred to by Eliphaz in 4:6). ${ }^{18} \mathrm{He}$ may be arguing that the doctrine should be understood more broadly, or that it has been unhelpfully applied in his case.

It is vital to see how the 'fear of God' idea is used in the dialogue. In this regard, the reader has an advantage over the participants, for the friends are not privy to the heavenly scenes in the prologue. The three friends conclude from Job's adversity that he no longer 'fears God'. Even when they do not use 'fear of God' terminology, they nonetheless urge Job to 'fear God' more as the solution to his problems (5:8-9; 8:20; 11:7-20). This advice must be viewed ironically by the reader, since the prologue has demonstrated that this is not the reason for Job's sufferings. The friends' analysis of Job's problem is seen as mistaken by the reader and is later corrected by God himself $(42: 7,8) .{ }^{19}$ While the solution is not revealed in the dialogue, the call to 'fear God' gives Job little comfort when God appears to be silent or absent. The friends, in proposing the 'fear of God' as the remedy, serve as a foil when the issues are finally resolved.

\section{Chapter 28}

The statement of $28: 28$ is clearly the peak of the 'fear of God'

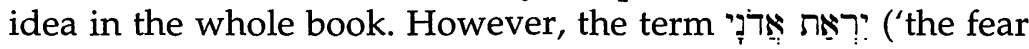

propounding the traditional wisdom teaching, but argues that Job is rejecting the traditional wisdom ideas here, citing 6:14.

${ }^{18}$ Fuhs, TDOT 6,312 , thus regards the use of 'fear of Shaddai' in $6: 14$ as equivalent semantically to the 'fear of the LORD'.

${ }^{19}$ Derousseaux, La crainte de Dieu, 335, therefore understands Job as rejecting the sapiential concept of the 'fear of the LORD', and the associated idea of divine justice. He regards Job as questioning the justice of God, the traditional idea of the sages, through the 'fear of God' idea. Job's insistence that he is just (27:6), and yet is not being dealt with justly leads him to question the doctrine of retribution associated with the 'fear of the LORD'. 
of the Lord') is a hapax in the Hebrew canon, while ('Lord, master') is a hapax in Job. ${ }^{20}$ Several factors indicate that this phrase is used here to denote the 'fear of the LORD'.

Firstly, chapter 28 is a poem extolling the virtues of human wisdom and reads like a mainstream wisdom discourse. Alter rightly notes that 'chapter 28, is in certain obvious ways cut from different cloth from the rest of the Book of Job. Lexically and stylistically, it sounds more like Proverbs than Job.' ${ }^{21}$ Secondly, it has already been argued that Job's 'fearing God' in 1:1 is a reference to the traditional wisdom idea. If so, the apparent inclusio between Job 1:1 and 28:28

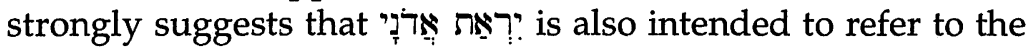
wisdom precept of Proverbs. Thirdly, the form of the saying in 28:28 appears to echo the 'fear of the LORD' mottos found in Proverbs 1:7; 9:10 and Psalm 111:10, and it seems to be placed here to allude to this foundational wisdom principle. ${ }^{22}$ Fourthly, this chapter is given a literary setting in the dialogue between Job and his friends. As has already been shown, 'fear of God' in the dialogue clearly refers to the traditional wisdom idea and, since this chapter functions as an interlude which reflects back on the dialogue, it is likely that it retains the same meaning here. Thus, most commentators find in 28:28, a reference equivalent to the traditional wisdom concept of the 'fear of the LORD'. ${ }^{23}$

Is the 'fear of God', then, being proposed in chapter 28 as the answer to Job's dilemma? Much will depend on how chapter 28 is understood. At first glance this chapter may

20P.P. Zerafa, The Wisdom of God in the Book of Job (Rome: Herder, 1978) 155.

21R. Alter, The Art of Biblical Poetry (New York: Basic Books, 1985) 92. Also N.C. Habel, The Book of Job (Old Testament Library; London: SCM, 1985) 392. Elements which reflect mainstream wisdom include the poetic structure with refrains, the learning from observation of human activity, the recurrence of the words 'wisdom' and 'understanding', the rich theology of creation, the details about mining and precious objects which are like an ANE onomasticon, the personification of Death and Destruction (v. 22), and the hypostatisation of Wisdom herself.

22So Becker, Gottesfurcht, 246-247.

23Whybray, Wisdom in Proverbs, 98; Fuhs, TDOT, 6, 312. 
suggest that Job is searching out something which is unobtainable, and which belongs only to God. On this view, Job should give up his quest and return to a proper fear of God. Hence, some use the conventional wisdom ethos of this chapter to tie Job into the more orthodox mainstream of the wisdom movement. Thus, in verse 28 , they see the book's answer: 'The

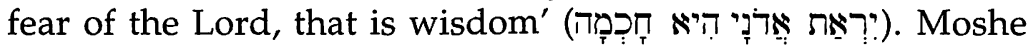
Greenberg has argued that this chapter is the anticipated conclusion-that 'for mankind wisdom consists of fearing God and shunning evil; more than that he cannot know. ${ }^{24}$ Such a view implies that true wisdom involves Job renouncing his earlier outbursts, complaints and protests, and turning back to 'fearing God'. However, the present context of Job 28 suggests a different reading of the chapter. Within the framework of the whole book, such a view would be asserted here in order to be corrected by the remainder of the book.

Surprisingly, very few commentators see that one's reading of this chapter is affected by its position in the book as a whole. After the three rounds of dialogue from chapters 3-27, the debate is interrupted by the poem about wisdom in chapter 28. Yet protest and complaint reappear in chapters 29-31 as Job rounds off the debate with his final summing up. Westermann observes that it cannot 'represent the high point of the book, as some interpreters assume; this is rendered impossible already by its location before the great concluding lament. ${ }^{25}$ Habel, too, is alert to this. He notes that the orthodox and traditional conclusion of verse 28 'serves as a deliberate foil for the climactic protestation of the hero which immediately follows (chs 29-31). The poet thereby emphasizes once again that the traditional orthodox answer... is not acceptable to Job. ${ }^{26}$ If

${ }^{24} \mathrm{M}$. Greenberg, 'Job', in R. Alter \& F. Kermode (eds.),The Literary Guide to the Bible (Cambridge, Massachusetts: Belknapp, 1987) 299. Similarly, J.H. Eaton, Job (Old Testament Guides; Sheffield: JSOT Press, 1985) 19.

${ }^{25}$ C. Westermann, The Structure of the Book of Job (Philadelphia: Fortress, 1977) 136.

26 Habel, The Book of Job, 393. See also S.A. Geller, "'Where is Wisdom?": A Literary Study of Job 28 in its Settings', in J. Neusner, B.A. Levine \& E.S. Frerichs (eds.), Judaic Perspectives on Ancient Israel (Philadelphia: Fortress, 1987) 173-174. 
'fearing God' was intended to be the answer of the book, it would have been given after Job's summing up, not before it.

Job 28:28 recalls $1: 1$, serving to remind the reader that Job was already like this. In chapters 1 and 2, Job had feared God and shunned evil, but that has given him no answers in the face of God's continuing silence.

Moreover, in the book as a whole, Job's protests are presented as legitimate courses of action for a righteous person confronted with the absence of God. It is unlikely that this is overturned here, since verse 28 occurs when the issues of the book are still unresolved. This implies that the maxim found in verse 28 is not the key to evaluating Job's protests.

A further factor suggesting that this chapter is, in fact, an anticlimax is the form of the expression, 'the fear of God, that is wisdom'. The 'fear of God' is no longer just the beginning or first principle of wisdom (Pr. 1:7); it is wisdom, seemingly asserting that the concept of wisdom is exhausted by, or equated with, the idea of the 'fear of God'. ${ }^{27}$ If so, this is an excessive claim, based on a fossilised misunderstanding of the book of Proverbs, and one that is qualified by the final form of the story of Job. ${ }^{28}$

The 'answer' given by this interlude is followed and qualified by chapters 29-31, as well as God's different verdict in chapters 38-42. This prevents it from being read as the answer or anticipated conclusion. While the contents of chapter 28 may be true, they are not sufficient to resolve Job's dilemma. It is revealing that, in chapter 29 , Job goes back to the days when he was the respected in the community for his wisdom, presumably because he 'feared God' and turned away from

\footnotetext{
27F. Michaeli, 'La sagesse et la crainte de Dieu', Hokma 2 (1976) 43: 'Il y a une sorte d'identification entre la crainte du Seigneur et la sagesse, au point que les deux termes sont practiquement interchangeables. Parler de la crainte de Dieu, c'est parler de la sagesse, et réciproquement. On pourrait presque dire que la crainte du Seigneur est le commencement, le milieu et la fin de la sagesse.' What Michaeli fails to see is how chapter 28 functions within the book-so that this is an excessive claim for the 'fear of God', and one that is rejected by the book as a whole.

${ }^{28}$ Goldsworthy, Gospel and Wisdom, 96 rightly suggests that the friends 'present the wisdom of Proverbs fossilized so that the timerelatedness of the proverbs is forgotten.'
} 
evil. That did not prevent his present distress, or give him an awareness of God's presence. The orthodox and traditional conclusion of $28: 28$ is thus undercut by chapters $29-31$, for there Job speaks of the way in which he lived 'fearing God', yet is left with his dilemma. His 'fear of God' did not fully resolve the issues raised in his struggle of faith. ${ }^{29}$

It is evident that $28: 28$ creates rather than removes the difficulty for Job. The friends have applied the doctrine to Job and urged him to turn from his evil which must have caused his suffering. Job has already replied 'I do fear God and turn from evil, yet my suffering continues.' That tension is not faced in this chapter, and therefore this wisdom interlude must be serving another purpose.

It has already been observed, in both Proverbs and Ecclesiastes, that the location of the 'fear of God' concept in the structure of a book is important for the overall interpretation of the book. Chapter 28 is a statement of mainstream wisdom orthodoxy, and is introduced by the editor/author so that it can be reconsidered in the light of Job's struggles and protests during the debate. The structure of Job precludes this being read as the anticipated conclusion, and the speeches that follow make that manifest. When rightly understood, therefore, this chapter does not preclude the legitimacy of Job's earlier complaints as he has been striving in faith for the presence of God. Job is not telling himself, nor being told, to revert to his earlier quiet submission. The perspective of chapter 28 is qualified when it is read as part of the whole book.

\section{The Elihu Speeches}

In Elihu's speeches (chapters 32-37), the idea of 'fearing God' occurs only once, at the conclusion of his final speech (37:24). It

${ }^{29} \mathrm{D}$. Robertson, The Old Testament and the Literary Critic (Philadelphia: Fortress, 1977) 46, comments: 'This is precisely the wisdom Job has followed all his life (chapter 1-2) and where has it got him: the ash-heap. Some wisdom!' More positively, Habel, The Book of Job, 392: 'is this the final solution of Job or the poet? Hardly! for clearly, "fear/piety" (yir'a) has not provided Job with the wisdom to understand the crisis he faced.' 
is, as in $28: 28$, in a very significant structural position. If the answer of the book is that Job needed to learn a true 'fear of God', then this strong closing note in Elihu's final speech would have been a suitable conclusion to the book. Instead, the contribution of Elihu is ultimately inadequate. Elihu's role within the book is to give the human verdict, summing up the words of Job and the friends, and delivering judgment. In such a context, it is likely that he means by the 'fear [of the Almighty]' the wisdom concept as used by the previous speakers-Eliphaz, Job and perhaps also its occurrence in chapter 28.

It is sufficient to point out that Elihu's implied remedy ('fear God') does not lead to a resolution of the issues in the book. While Elihu says much that is true, his human verdictthat Job is in the wrong, and God does not appear to humanssolves nothing. It is essentially overridden by the Yahweh speeches which follow immediately, and the epilogue, where Yahweh declares Job to have spoken about Him what is right $(42: 7,8)$.

\section{The Yahweh Speeches and the Epilogue}

Even more significantly, the idea of 'fearing God' is not brought up in the Yahweh speeches nor in the epilogue. This strongly suggests that the issue of the 'fear of God' is not part of the solution of the book. The Yahweh speeches and the epilogue are crucial for interpreting the book as a whole, and yet they make no reference to the 'fear of God'. In those very parts of the book where the central issues are resolved (as far as they are resolved!), the 'fear of God' idea speaks with a deafening silence!

If $28: 28$ contained the anticipated conclusion, then it would need to resurface either when God finally speaks, or when the narrator concludes. Yahweh has twice said that Job 'fears God' (1:8; $2: 3)$; the narrator agrees (1:1); even the Satan concedes that Job 'fears God', though he questions his motive (1:9). Nowhere in chapters 38-41 does Yahweh claim that Job has given up his 'fear of God'. Whether Job 'fears God' for nothing is the question that hangs over the book; Yahweh's verdict is that his servant Job spoke of him what was right 
$(42: 7,8)$. Surely this suggests that the overall message of the book is not that Job, through his sufferings, came to a truer understanding of what it means to 'fear God'. It has already been established that an attitude of questioning the traditional precepts of mainstream wisdom is still consistent with the 'fear of the LORD'. It appears that, all along, Job's strong protests and complaints have been legitimate expressions of the faith of a righteous person.

The relationship between God and Job, seemingly broken by God's silence, is restored without any need to refer to the 'fear of God' idea. Thus, the Yahweh speeches and the epilogue perform an important literary function. For the reader, the non-mention of the 'fear of God' concept shifts this motif to the sidelines as the issues of the book are resolved in other ways.

\section{Implications for the 'Fear of the LORD' Idea in Wisdom}

What consequences flow from this view for the idea of 'fear of the LORD' in the wisdom corpus? It has been established that, despite the variety of terminology in the book of Job, the 'fear of the LORD' concept is being referred to in the prologue, the dialogue by Eliphaz and Job, in chapter 28 and at the conclusion of Elihu's speeches.

It seems, therefore, that there are three main options. The first possibility is to define the 'fear of God' more broadly. Thus, its semantic boundaries might need to be stretched to include such responses as calling out to God, protesting to God, crying for justice from God. Certainly, complaint and protest, which characterise much of Job's words in the dialogue, have a legitimacy in the book as a whole. Job's angry and puzzled cries are not to be met with a glib rejoinder that he needs to fear God more. Eliphaz tries that, but God himself rebukes him in $42: 7,8$, saying 'you have not spoken of me what is right'.

The second possibility is the 'fear of the LORD' concept retains its traditional meaning, yet finds its application 
qualified. On this view, the friends use the concept with its usual meaning, as the solution to Job's problems, yet this is rejected in Job's case (and presumably in some other cases) by both Job and Yahweh. If so, the 'fear of the LORD' is still important to the wisdom strand, but it is not all that is important. The need to 'fear God' is still central and undoubtedly true, yet it is not the whole truth.

Several factors support this second option. Chapter 28 defines the 'fear of God' narrowly, and this definition is of limited usefulness in explaining Job's case. More decisively, the non-mention of the 'fear of God' in chapters 38-42 implies that there is no attempt to re-define or nuance the term. Its omission from the crucial final sections of the book are best explained by the view that it is beside the point in Job's case. Its applicability is being qualified rather than its content being broadened.

A third option is that the book of Job contradicts the 'fear of the LORD' notion of Proverbs. Derousseaux, for example, argues that Job is rejecting the sapiential teaching about both the 'fear of the LORD' and divine justice. ${ }^{30} \mathrm{He}$ is wrong on both counts: Job clings on desperately to divine justice throughout the book, refusing to give up either God or justice; similarly, the idea of the 'fear of the LORD' is not rejected, but its ability to cover the whole field of human response is qualified. The book of Job does not deny that the 'fear of the LORD' is the beginning of wisdom, but it does show that there is more to acting wisely than a narrow view of what it means to 'fear God' would imply. It qualifies rather than contradicts this pivotal wisdom claim. Just as the doctrine of retribution is qualified, so too the 'fear of the LORD' idea is clarified (or perhaps broadened?) by showing its limitations.

The issues of divine justice and retribution offer instructive parallels. Scholnick argues that the Yahweh speeches serve to broaden Job's understanding of justice from a judicial to an executive sense. ${ }^{31}$ Thus, the meaning of מְִָּּפט

${ }^{30}$ Derousseaux, La crainte de Dieu, 335.

31S.H. Scholnick, 'The Meaning of mišpāt in the Book of Job', JBL 101 (1982) 521-529. 
('justice') is to be understood more broadly to include God's wise governing of all of creation, as painted for Job in chapters 38-41. On this view, Job's call for justice is resolved by widening Job's concept to encompass his design or purpose evident in all creation. This is to claim that the book of Job redefines justice, rather than rejects the view that God is just.

Scholnick may well be correct here, but the Yahweh speeches might better be understood as qualifying rather than broadening the concept of justice. Job's self-confessed limitation in knowledge (42:3) is rather, on this view, Job's apparent understanding that the principles of retributive justice constituted the sole rationale for God's actions. Job thus comes to see that God's purposes in the universe are wider than justice. The idea of retributive justice as espoused by the friends, and accepted to a large extent by Job, is neither the reason for Job's sufferings, nor the solution to his existential dilemma. The teaching in Proverbs about retribution is true, but it is not all that is true, and it is this that Job comes to see.

Thus, the epilogue seems to reinforce the mainstream notion of retribution by restoring Job's possessions, the expected accompaniment of a righteous person. The doctrine of retribution is not negated by the book of Job, but it is qualified. Clines notes that the Yahweh speeches, in neither affirming or denying the retributive principle, show that it is not as fundamental to understanding the world as it is thought to be by most of the characters. In other words, the doctrine is marginalised, for it is not the decisive doctrine as far as Job's case is concerned. ${ }^{32}$

In a similar way, this article suggests that the 'fear of God' is qualified in the book of Job. The book does not seek to overturn the mainstream wisdom concept of the 'fear of the LORD', but it establishes that it is beside the point in Job's case. It is neither the reason for his suffering, nor the solution to his struggle of faith. The function of the 'fear of God' motif in the book of Job is to insist that the totality of the wise living cannot be subsumed under the 'fear of the LORD' concept. While the 'fear of the LORD' is the beginning of wisdom, it is not all that

${ }^{32}$ D.J.A. Clines, Job 1-20 (Dallas: Word, 1989) xlv-xlvi. 
there is to wisdom. Wisdom is a wider category than the 'fear of the LORD'.

\section{Conclusion}

Lamenting and protest must therefore be seen as legitimate human responses to God. An appeal to 'fear God' more may often be appropriate, but it can also stifle authentic, honest faith in times of great hardship. There is sometimes a need, if one can misquote Luther, to 'fear God boldly'! One beauty of the lament is that conversation is kept going, not cut short. In the wider canon of christian scripture, it is no surprise to hear the words of another who is blameless and upright-the crucified Jesus-utter the words of a lament Psalm ('My God, my God, why have you forsaken me?-Ps 22:1) as he is hanging in pain on a cross.

On a wider plane, this understanding of the fear of the LORD has implications for the place of wisdom in the OT as a whole. It seems that not all that the wisdom books say about human responses can be incorporated into an OT covenantal theology under the rubric of the 'fear of the LORD'. The book of Proverbs insists that this idea is central, but Job (and perhaps also Ecclesiastes) seems to insist that there is a wider range of legitimate human responses. It is not adequate to tie the wisdom distinctives into an OT covenant theology on the basis that both the covenant and wisdom strands speak of the 'fear of the LORD'. The book of Job insists that wisdom literature speaks of other ideas as well, ideas that cannot simply be subsumed under the 'fear of God'. A richer way must be sought for the integration of the wisdom and covenant strands in an OT theology. ${ }^{33}$ Wisdom cannot simply be subsumed under covenant, but must instead be incorporated in a way which does more justice to the distinctives of the wisdom literature.

${ }^{33}$ The most suggestive framework for this is found in J. Goldingay, Theological Diversity and the Authority of the Old Testament (Grand Rapids: Eerdmans, 1987). For an outline and critique of Goldingay, see L. Wilson, 'The Place of Wisdom in Old Testament Theology', Reformed Theological Review 49 (1990) 60-69. 
The 'fear of God' thus functions in the book of Job to broaden the reader's understanding of both wisdom and faith. Neither are exhausted by the 'fear of God', but in both the 'fear of God' will continue to have an important role to play. 